\title{
MUTUALITY AND REGULATION: THE TRANSITION FROM MUtUal to PUblic in the SOUTH African LONG- TERM INSURANCE INDUSTRY
}

\author{
Grietjie Verhoef* \\ University of Johannesburg \\ gverhoef@uj.ac.za
}

January 2012

\begin{abstract}
The mutual structure of various financial institutions has changed internationally, especially during the late 1980s and early 1990s. Various explanations have been offered. Some commentators argue the mutual organisational form has become redundant, others consider structural changes in the financial services industry as the main reason for organisational changes. In the United Kingdom the stronger emphasis on profitability had a profound impact on the decision to demutualise many building societies. In the USA the failure of mutual savings and loan associations resulted in demutualisation as a rescue strategy. This paper will explore the specific circumstances in South Africa of the changes in the mutual organisational form of building societies and insurance companies. The mutual form of organisation has a long history in South Africa. This paper will explore the reasons for the early choice of mutuality and the recent forces leading to the demutualisation of companies in order to list as public entities on stock exchanges, both in South Africa and abroad. South Africa experienced varying degrees of international isolation and sanctions, but, in the financial services industry, a strong international connection was sustained. The South African experience will be considered against the international changes in the financial services industry as well as the regulatory changes in South Africa. The paper will explain the peculiar South African conditions as the context for the organisational changes in South African mutual.
\end{abstract}

Keywords

Demutualisation, insurance, globalisation, financial services, diversification, market control.

*Prof Grietjie Verhoef is professor in the Department of Accountancy at the University of Johannesburg, South Africa 


\section{INTRODUCTION}

In the last two decades financial markets and financial institutions experienced a process of radical readjustment spurred on by changing regulatory environments, technological innovation and the globalisation of financial systems (Treptow, 2006; Meador \& Chugh, 2006). This has become a global phenomenon and resulted in a remapping of the financial landscape as markets adapt to new forms and ways of conducting business. An outcome of this change has been a reassessment of the suitability and value of particular types of organisational structures and their relevance in the modern financial environment. Since the 1980 s a wave of 'demutualisation' has occurred across a range of industries from stock exchanges to building societies, savings and loans associations and insurers. (See McKnight \& Gething, 1996; Carson, Forster \& McNamarra, 1998; Chaddad \& Cook, 2004; Meador \& Chugh, 2006; Treptow, 2006.) Demutualisation is defined as the process by which the ownership and governance structure of user-owned and controlled organisations is transformed, from a mutual entity to a for-profit outsider-dominated proprietary organisation (Battilani \& Schröter, 2011:3; Treptow, 2006:1). The common aspect of demutualisation is the loss of membership rights in the mutual entity upon the transfer of policies to a public listed entity. Apart from this commonality, no two demutualisation processes are the same (McKnight \& Gething, 1996:9). In all markets affected by such transitions, as well as in South Africa, this had a dramatic effect on the life insurance markets where some of the oldest and largest mutual long-term insurance companies demutualised in the last decade.

Whilst a number of studies have analysed demutualisation in various markets (Mayers \& Smith, 1981; Hansmann, 1985, 1996; Mayers \& Smith, 1986; McNamara \& Rhee, 1992; Mayers \& Smith, 1994; Carson, Foster \& McNamara, 1998; Leyshon \& Pollard, 2000; Stephens, 2001; Mayers \& Smith, 2002; Tyler, 2003; Marshall, Willis \& Richardson, 2003; Carrasco, 2004; Chaddad \& Cook, 2004; Meador \& Chugh, 2006; Talbot, 2010), the South African context remains unexplored. In Britain the demutualisation of some of the country's largest building societies occurred as progressive deregulation, culminating in the Building Society Act of 1986, which increased competition and pressures for diversification (Martin and Turner, 2000; Stephens, 2001; Cook, Deakin \& Highes, 2001). Contextual analysis of the forces leading to demutualisation and their impact has not been conducted on the South African financial markets. It is at this level that a deeper understanding can be gained of the cultural and organisational shift from one form of ownership and governance to another. The aim of this paper is to explore the context of the demutualisation process in South African long-term insurance markets. The experience of organisational change in South Africa can provide a number of insights into the manner in which firms adjust to changes in regulatory and competitive environments.

The paper explains the market and regulatory context of the long-term insurance industry in South Africa since the early 1980s. Regulatory changes outline the context within which the business of the long-term insurance industry had to adapt. The paper explores the changes in the nature of the business of the long-term insurance industry in order to offer an explanation for the decision to change the organisational form, which is to demutualise. Access to the private archives of Sanlam (one of South Africa's major insurers) enables a more in-depth explanation of the Sanlam decision to demutualise in 1998. 


\section{THEORETICAL CONTEXTUALISATION OF DEMUTUALISATION}

Mutual associations have played an important role in the development of life insurance markets in most Commonwealth countries, as well as in South Africa. The essential difference between a mutual structure and other forms of governance revolves around the issue of ownership arrangements. In a mutual firm, ownership rights are assigned to members, in the case of an insurance company this generally refers to policyholders (Hetherington, 1969; Fama \& Jensen, 1983; Mayers \& Smith, 1981; Mayers \& Smith, 1994). Hansmann's (1996) theory of ownership provides a useful tool to analyse the relationships in a mutual organisation and how these differ from other corporate structures. Ownership consists of two dimensions: rights associated with the management and control of the organisation and rights associated with the distribution of income generated by the activities of the firm.

In a mutual organisation, residual control rights and residual income rights coincide, thus preventing potential conflict of interest that may occur when the rights of other stakeholders are involved. Members have rights attached to the management of the company and exercise these rights by appointing a board of directors to oversee their affairs. This can be compared with stock companies that are investor-owned, involving a third party in the ownership relationship. The three parties are the shareholder, management and the policyholder. A stock company that is a public entity, has shareholders who do not necessarily own insurance policies, but seek optimal returns on their investment. These interests may be short-term or long-term. Policyholders have more long-term expectations of stable returns on policies, which do not have to realise in the short term. Shareholders can sell their shares any time, but policyholders usually have a longer-term expectation of growth on their contractual investment. These interests may be conflicting and create opposing interests to be considered by management.

Scepticism has been voiced about the 'effective' control by policyholders. Hetherington wrote: 'The mutual insurance policyholder is not really the owner of the insurance corporation...The...ineffectiveness as an owner is primarily a consequence of the nature of his relationship with the insurer: he is nothing than what he considers himself to be - a consumer of services offered by management' (Hetherington, 1969:1086). The limitations of policyholders' effective control were debated by other analysts of the mutual form of organisation (Mayers \& Smith, 1986: 72-77; Mayers \& Smith, 1994:640-642; Cagle, Lippert \& Moore, 1996: 343-347).

Further studies identified a change of management culture, as a consequence of changes in the operating business environment, as a reason for decisions to demutualise (Marshall et al., 2003). A change in macro-economic paradigms has also been suggested a factor influencing changes in the organisational forms of mutual firms (Talbot, 2010). Leyshon and Pollard (2000) argue that globalisation has contributed to the 'transformation of regulatory space', which, in the long run, resulted in convergence of practice and organisation in different industries. The change in political economy, dominant ideologies, management culture and choice of financial service providers challenged mutual structures. Talbot (2010) argues that the growing support for the values of free markets for products and contracting property-owners since the early 1980 s paved the way for the removal of anti-competitive practices, such as the protective regulatory environment of building societies in the UK, and the encouragement of competition, innovation and a replacement of oligarchic practices by an enabling environment of choice. The demutualisation strategy was, therefore, promoted as a component of the shareholder-value ideology. 
Important reasons for the mutualisation of insurance companies were the perception that stock companies charged a substantial premium on insurance policies, and that an incentive/contracting conflict existed between managers of stock companies and policyholders. The stock companies' management might be inclined to seek optimal returns on shareholder funds on a different time scale from policyholders, while policyholders' interests might take a longer-term view (Mayers \& Smith, 1986; McNamara \& Rhee, 1992). The reservations about effective policyholder/owner control led to research using agency theory to assess the impact of organisational structure on firm efficiency (Jensen \& Meckling, 1976). This seminal article led to extensive research into optimal organisational structure and cost/benefit trade-offs between mutual and stock companies. On the one hand, Carson et al. (1998) found that mutual companies attempted to reduce contracting costs by unifying claimholders interests with that of customers, while stock companies incurred agency costs associated with the owner/customer conflict. The latter option offered an opportunity to address control over management, which was less effective under the mutual structure. Economic explanations for the emergence of mutual institutions revolve around a desire for 'self-help' (Nicols, 1967) and market failure leading to information and agency problems (Fama \& Jensen, 1983). Hansmann (1985) suggests that co-operative forms of governance emerged in life insurance markets in response to several problems: first, the difficulty of writing long-term contracts under conditions of uncertainty. It was difficult to predict unforeseen contingencies over a substantial period of time, which increased the risk of loss. The governance structure of mutual companies enabled facilitation of such problems (Hansmann, 1985:129-132). The second problem is information asymmetry. Hansmann (1985:132) argues that policyholders' ignorance on insurance contracts lead to agency relationships where agents take decisions on their behalf. Fama and Jensen (1983:347) argue that mutual companies are better equipped to deal with the principal/agent problem. When the agent's decision deviates from that which may have been made by the policyholder, a residual loss occurs, a situation mutual companies are better positioned to resolve. Policyholders have rights of ownership and the ability to participate in decision-making processes (Carson et al, 1998:1-2). The third problem mutual companies are better able to address is adverse selection (Hansmann, 1985:132-33). This is done by locking a policyholder into the agreement for a specific length of time and using front-loaded premiums to make it expensive to exit. Policyholders' activism through management and control positions can prevent opportunistic and adverse operations. Recently Michie et al. argued that mutual companies display advantages of enhanced stakeholder engagement and community involvement (Michie, Llewellyn, Anderson, Eyre \& Hunt, 2009). The actual experiences of many mutual organisations(Llewellyn, 1997) were that they developed into large financial entities with increased separation between management and members (Chaddad \& Cook, 2004).

Demutualisation is attributed to a number of causes. Two most commonly referred to causes are the efficiency thesis and the expropriation thesis (McNamara \& Rhee, 1992:235-236; Cagle et al., 1996:351-355, 367; Cummins, Weiss \& Zi, 1999:1254-1255; Chaddad \& Cook, 2004:577; Meador \& Chugh, 2006:13). The efficiency hypothesis argues that the organisation that survives is that which can cover costs and deliver the product to the consumer at the lowest possible price. Initially Mayers and Smith (1986) found that mutualisation was efficiency enhancing, but Cagle et al. found the outcome of demutualisation to be "... a neutral mutation" (Cagle et al, 1996:367). On the other hand, it has been argued that mutual structures, based on the principle of a common bond between members, have increasingly become out-dated and pressures for a more efficient structure have grown in response to the changing commercial environment (Meador \& Chugh, 2006:10). 
The commercial environment changed as a result of technological innovation that revolutionised information and communication technology. During the 1980s and 1990s, new technology revolutionised the sophistication of and speed with which services could be provided to consumers. Especially in the securities exchange environment, Treptow noted that these changes altered and streamlined the provision of trading services fundamentally (Treptow, 2006:50). Trading could take place from the location of execution and investors were offered products chosen from different markets. This enhanced the appetite for a greater variety of securities. In turn, these developments allowed financial institutions to differentiate between product offerings to different customer groups (Llewellyn, 1992: 249; Llewellyn, 1996: 168). Not only did life insurers offer products resembling products offered by other types of financial institutions, but these firms also began providing substitutes for life insurance - a blurring of functions developed in the financial services industry (Fama \& Jensen, 1983:341). New technology and new marketing techniques also led life insurers to adopt different corporate strategies. In response to these innovations in the industry, regulatory environments also changed. Masulis explained the impact of the Federal Home Loan Bank Board's decision in 1976 to allow federally chartered mutual institutions to convert, eventually resulting in the 1982 Deposit Institutions Act extending demutualisation as an option to all USA states (Masulis, 1987:35). Market changes in the 1980 s contributed to extensive demutualisation worldwide. Corporations wanted to gain access to additional capital, and team up with other financial services organisations using subsidiaries, mergers and acquisitions, establishing greater flexibility in business operations. Revised corporate strategies were implemented based on efficiency, adaptability, growth, and the development and expansion of new product lines (McNamara \& Rhee, 1992; Perks, 1991; Meador \& Chugh, 2006).

A further explanation of the trend to demutualise is the potential wealth transfers created by individual asset allocation. The expropriation hypothesis focuses on the incentives to convert communal wealth to private wealth creating a windfall gain to individual members. It contends that demutualisation may be motivated by the possibility of transferring wealth to shareholders and management at the expense of policyholders (Mayers and Smith, 1986; Cagle et al., 1996; Carson et al., 1998; Chaddad \& Cook, 2004). Later studies such as that by Erhemjants and Leverty (2007) failed to find evidence to support this hypothesis. They found that value-based explanations were more valid justifications for demutualisation. Although wealth transfers were observed in the case studies on demutualisation conducted by Hansman, he noted that '.. if the mutual form is less efficient than the stock form today, it is not owing to wealth incentives to minimize costs, but rather to other factors such as restricted access to capital and inability to diversify' (Hansman, 1985:137). The 'wealth transfer' process can thus be seen as placing assets in the hands of individual owners (stock owners) as well as enabling the stock company the opportunity to approach the market for further capital to effect the expansion incentivised by new opportunities in the market. A strong incentive to demutualise was the increased ability and ease with which stock insurers could raise capital, allowing them to take more risk than mutual insurers (Viswanathan \& Cummins, 2003).

A third explanation for a change in ownership structure is the causal relationship between organisational form and changes to the 'rules of the game' (regulatory environment). On a national and international level, the deregulation and liberalisation of capital markets and their institutions caused a fundamental overhaul of the entire financial services industry. Systematic political transformation was a sine qua non to facilitate global competition. This happened inter alia through the formation of the European Union, which allowed competition to cross national borders and reduce economic fragmentation (Treptow, 2006). Financial services markets 
transformed globally. This transformation had more impact on open markets and Rajan and Zingales (2003) found that a positive correlation exists between the degree of openness of an economy and the development and advances of its financial system. Treptow, therefore, argues that it would be safe to assume that '... the propensity to demutualise would increase as the degree of openness of an economy increases' (Treptow, 2006:55). Global deregulation has also coincided with changes in demand for financial services, which in the case of the long-term insurance industry resulted in a significant shift away from traditional long-term insurance products. Demutualisation represents a structural change in response to these scenario adjustments in the financial landscape.

This is exactly what Chaddad and Cook (2004) observed, namely that conversions often occurred after periods of dramatic institutional or market change which altered the 'rules of the game'. While some degree of 'market failure' contributed to the emergence of mutual companies, increased competition in a more liberalised market environment called for a response to such opportunities. There is evidence to suggest that this was the case in the American life insurance industry in the 1990s and early 2000s (Viswanathan \& Cummins, 2003; Meador \& Chugh, 2006). Similar trends were evident in other financial markets such as the building society sector in the United Kingdom (Martin and Turner, 2000) and securities exchanges since the early 1990s (Treptow, 2006). A new era of a more highly evolved market of empowered and sophisticated customers seeking wealth management in a deregulated financial services industry and global competition in the life insurance market made traditional life insurance as the main line of business obsolete (Meador \& Chugh, 2006).

The response to the fundamentally changed environment of mutual companies led to a strategic repositioning of those companies, which Skaerbaek and Tryggestad (2010:109) called 'the use of accounting devices' to reformulate strategy to promote efficiency. The authors use the Actor Network Theory (ANT) to combine various elements in motivating and devising a new strategy for the enterprise. In the study of Sanlam it will be illustrated how accounting devices such as financial reports, audit committee reports, investments returns and financial ratios, were employed internally to motivate the strategic overhaul of the mutual assurer. Callon (1986) argued that strategic management accounting was increasingly used to mobilise objects and logic that seek to encapsulate what strategy is. From the application of accounting devices internally in the firm, a similar argument about the use of accounting devices to influence the external environment of the firm was made. Mouritsen and Kreiner (2003) observed that accounting devices were successfully linked to the emergence of a strategy to make the firm attractive and saleable in a series of mergers and acquisitions. To rationalise demutualisation, accounting devices were instrumental in making the newly demutualised concern attractive to the investor community as well as to retain policyholders.

In offering a synthesis of the discourse on demutualisation Battilani and Schröter (2011) identified five categories of motives driving the process:

- Organisational isomorphism, that is, the tendency of one unit in an environment to want to resemble other units faced with the same environment. If an environment is more efficient and competitive, then entities in that environment would seek to conform to those circumstances.

- Cultural reasons, which refer to the tendency to follow the privatisation trend should that become the dominant culture of the period (also see Birchall, 1998).

- Expropriation by managers (also see Mayers \& Smith, 1986). 
- Political reasons, such as, that socialism needs to be replaced by privatisation and free enterprise (also see Wegren, 2009; Amelina, 2002).

- Inefficiency and a lack of growth prospects, which implies that organisational performance can be achieved by ending restrictive co-operative arrangements (also see Schrader, 1989; Collins, 1991; Fulton 1995; Cook 1995; Hölstrom, 1999).

The study of demutualisation in South Africa suggests that there was an interplay of several of these motives. The changing environment of deregulation promoted a degree of isomorphism. Cultural values aligned to privatisation favoured demutualisation. While managerial expropriation and political reasons to terminate socialism were not apparent, the increased focus on organisational efficiency and competitiveness indeed served as strong motives for demutualisation.

The purpose of this paper is to investigate how these considerations and market conditions influenced the decision of South African long-term insurance companies to demutualise.

\section{FINANCIAL MARKET REGULATION}

The South African economy is an open economy, vulnerable to international shocks and business cycle movements (Hodge, 2001:52; Jones, 2002:195). In order to develop the domestic market, protectionist policies were introduced in the late 1920s and by the Second World War a domestic industrial sector had emerged, supported by a well-developed financial services sector. The South African economy was well positioned to benefit from the rapid post-war economic expansion. The most impressive domestic growth occurred in the 1960s. In this period of high tariffs, import-substitution industrialisation and emerging political isolation, an inwardlooking economy was taking shape. The regulation of banks and insurance companies as the intermediaries responsible for the management of savings, capital and investment resembled the increasingly restrictive economic policies of the time.

Post-war monetary policy was based on the perception that only retail banks created money and, therefore, policy was aimed at controlling money creation in the economy. In the subsequent Keynesianism of the 1950s and 1960s the emphasis shifted to demand management by means of fiscal policies. In the late 1960s and 1970s monetary policy was determined by technical manipulation of various liquid assets, of which money was only one. Direct monetary control measures were only replaced by market-oriented monetary policy measures towards the late 1980s (Styger \& Saayman, 2012; Hodge, 2001).

The insurance industry was less regulated. Competition was open to companies registered in compliance with the Insurance Act, No 37 of 1923. Despite the fact that a very large number of insurance companies had always been active in the market, a few long-term companies dominated the market. In 1925 it was African Life Assurance Corporation, Old Mutual, the Southern Life Assurance Company and Sanlam (South African National Life Assurance Company, est. 1918). No statutory limitations were introduced in the next insurance act, No 27 of 1943, on operations by foreign-owned insurance companies, but compulsory investment in government securities and bonds were introduced. These requirements sent some foreign insurance companies packing, but competition remained strong (Benfield, 1997:580-582). In 1973 the insurance legislation was amended to require incorporation of all insurance companies in South Africa as well as majority shareholding by South Africans (Verhoef, 2010; RP87/1970:213-218). This inward-looking development was a response to growing international pressure on South 
Africa and an attempt to secure access to investment funds given the threat of crippling sanctions. Banks were never permitted to own insurance companies and, therefore, the insurance industry was not absorbed by 'bancassurance' (Verhoef, 1987:151-161). In the midst of the debt standstill of 1985 (Goedhuys, 1994:159-162), most remaining foreign shareholders disposed of their shareholding in South African insurance companies, leaving the insurance industry fully insulated in the domestic market (Singleton \& Verhoef, 2010).

TABLE 1: Gross Domestic product (GDP) growth rates and Consumer Price Index, 1985-2000

\begin{tabular}{|c|c|c|}
\hline & GDP (at 1995 constant Prices) \% & $C P / \%$ \\
\hline 1985 & -1.2 & 16.3 \\
\hline 1986 & 0.0 & 18.6 \\
\hline 1987 & 2.1 & 16.1 \\
\hline 1988 & 4.2 & 12.0 \\
\hline 1989 & 2.4 & 14.7 \\
\hline 1990 & -0.3 & 14.4 \\
\hline 1991 & -0.1 & 15.3 \\
\hline 1992 & -2.1 & 13.9 \\
\hline 1993 & 1.2 & 9.7 \\
\hline 1994 & 3.2 & 9.0 \\
\hline 1995 & 3.1 & 8.7 \\
\hline 1996 & 4.2 & 7.4 \\
\hline 1997 & 2.5 & 8.6 \\
\hline 1998 & 0.7 & 6.9 \\
\hline 1999 & 1.9 & 5.2 \\
\hline 2000 & 3.1 & 5.3 \\
\hline
\end{tabular}

Source: $\quad$ South African Reserve Bank, Statistical Data, 1985-2000

The South African economy was not performing well during the 1980s. TABLE 1 shows that GDP in real terms averaged $1.2 \%$ per annum in that decade. By 2000 only a mild recovery was achieved. Fixed investment declined annually from 1981 and the operating surplus of business, expressed as a percentage of GDP, almost halved from 28 in 1980 to 15 in 1989. Both consumer prices as well as production prices increased in double digits from 1974 until 1993. The CPI (inflation TABLE 1) was $16.3 \%$ in 1985 , rising to $18.6 \%$ in 1986 and declining sluggishly towards the end of the 1990 s, just to rise again to $13.9 \%$ in 1992 . By 2000 the inflation rate was down to $5.3 \%$. The balance of payments was in negative territory as a consequence of the decline in the gold price and high oil prices. Commodity prices weakened substantially, with gold falling from US\$613 per fine ounce in 1980 to an average of US\$317 in 1985, with a slight recovery to US\$383 in 1990. Deflationary and strict monetary policies, coupled with international sanctions and debt 
repayments, reduced imports and foreign reserves. These factors placed severe strain on the ability to stimulate the economy. The exchange rate also weakened considerably from 1985 . The debt standstill and disinvestment made South Africa a capital exporter, diverting domestic output from domestic needs to external demands (Goedhuys, 1994:146; Maasdorp, 2002:17-18).

International trends opened up markets and liberalised monetary policies. Trinchet noted that the contours and mode of operation of financial systems were reshaped by the combination of globalisation of economies and their transition to market mechanisms (Trinchet, 2003:247). South Africa followed the trend. The Commission of Inquiry into the Monetary System and Monetary Policy in South Africa (RP70/1984 - known as the De Kock Commission) proposed the deregulation of financial markets. Full deregulation was not implemented, because the government was hesitant to scrap exchange control and open the market to foreign competition. Internal financial market liberalisation was effected by the Financial Services Amendment Act, No 106 of 1985. This act ended the SARB right to use direct monetary control instruments in monetary policy. Restrictions on building societies to perform certain typical bank functions, such as offering current account facilities, were also lifted (Skinner \& Osborn, 1992; Jones \& Muller, 1992). Building Societies, many of them mutual, were required by the Building Societies Act of 1965 to invest heavily in government stock, but during the liquidity squeeze of the 1980s, rates on government stock rose sharply and prices declined. This resulted in capital losses by building societies and by March 1982 the five largest building societies posted a loss of almost R300 million over a two-year period. Building societies were also restricted by law to raising more than $5 \%$ of their funding from the short end of the market. Banks seized the opportunity to enter the home loan market. This problem was resolved through financial deregulation. Banks' and building societies' functions converged and banks bought ailing building societies. In the course of this reconfiguration of the bank-building society landscape in South Africa, many of the mutual building societies were absorbed by listed banks, thus ending their mutual character (Skinner \& Osborn, 1992:65).

Foreign shareholders in the large South African commercial banks such as Standard Bank and Barclays Bank withdrew in the light of the debt standstill and growing international pressure. The shares in those banks were acquired by the cash-rich insurance companies, which led to a reverse situation from the Australian experience. Deregulation reduced entry barriers (but not to foreign investors in domestic banks) and financial market segmentation was reduced, but insurance companies acquired control over banks. A reconfiguration in the South African insurance market resulted in the domination of the domestic market by five long-term insurance companies: Old Mutual, Sanlam, Momentum, Liberty and Metropolitan. These companies controlled in excess of $90 \%$ of the total assets in the industry (FSB, 2009; Ernst \& Young, 2004; Von Wielligh, 2005). The former big banking groups emerged as partners of new financial services conglomerates with the long-term insurance companies the anchor shareholders. The Nedbank Group was controlled by Old Mutual, the oldest surviving South African insurance company. The Standard Bank Investment Corporation (SBIC) emerged with the Liberty Group as controlling shareholder. Sanlam had a controlling interest in the ABSA Group (Amalgamated Banks of South Africa) and the Southern Life Assurance Company and Momentum Life Assurance Company were incorporated in the First Rand Group, which is the successor to First National Bank after the latter was acquired by Rand Merchant Bank (Verhoef, 2009; Verhoef, 2003; Benfield \& Vivian, 2003; Vivian, 2007). The Southern Life Association, which was a mutual long-term insurance company, merged with Momentum Life, the insurance company in the First Rand Group. The Southern Life Association did not demutualise as a strategic business decision, but was demutualised in the take-over transaction (Skinner \& Osborne, 2002; Jones, 2002). The two 
largest long-term insurance companies, Old Mutual and Sanlam, also control the two largest short-term insurance companies, i.e. Mutual and Federal and Santam, respectively (Vivian, 2007).

The reconfiguration of the South African financial services market after the late 1980s deregulation resulted in the demise of building societies, extensive merger and acquisitions in the banking sector (similar to the USA, see Fama \& Jensen, 1983) and cross shareholding by the large long-term insurance companies in the big banking conglomerates. Banks gradually started to offer insurance products to clients and non-clients ('bancassurance'), as brokers placed insurance with their own insurance companies, to be underwritten by their shareholder insurance partner (Jones, 2002; Benfield \& Vivian, 2003). This development coincided with the proliferation of new retirement products in competition with traditional life cover, which caused an absolute decline in demand for life insurance. Banks and insurance companies, mutual companies, as well as private equity enterprises, were locked into financial conglomerates, which undermined industry competition. Alternative business strategies had to be devised.

The changing landscape in deregulation and the political changes in South Africa by the early 1990 s had an impact on the corporate strategy of South African long-term insurance companies. Exchange control since the 1970 s had prevented long-term insurers from investments overseas, but by the early 1990 s significant relaxation of exchange control changed the strategic options open to long-term insurers. South African long-term insurance companies showed a growing interest in exploring global investment opportunities and refocusing investments. These developments coincided with the de-concentration of conglomerates (unbundling). The need to strengthen the business focus and to operate freely in international markets complemented one another. More flexibility in international operations could enhance synergies amongst focused business concerns, in and outside South Africa. Domestic constraints on business diversification and investment opportunities were addressed in the deregulated market after 1985.

\section{LONG-TERM INSURANCE PERFORMANCE IN SOUTH AFRICA, 1985-2000}

The long-term insurance industry in South Africa is an important role player in the retirement fund sector. The political economy of domestic security, the inward-looking monetary policies, the legacy of protectionism and exchange controls from 1939, locked the bulk of South African savings within the country. A substantial part of those savings were retirement funds, such as pension funds, provident funds and retirement annuities. (This amounted to $57.33 \%$ of the total long-term insurance market - see discussion below). In the absence of a state social welfare system, South African employers have established occupational retirement plans, managed by separate bodies, fund managers or insurance companies. Traditionally long-term insurance companies managed the bulk of these retirement funds (Vivian, 2007). Changes in employment security would, therefore, impact directly on the funds under long-term insurance management.

The demand for traditional life insurance products from long-term insurance companies changed fundamentally in the turbulent times of the 1980s and 1990s. To assess these changes, it is necessary to look at the flow of funds to and from the industry. The number of long-term insurance companies declined from 57 in 1985 to 38 in 1990, but increased to 70 by 2000 (see TABLE 2). In this market two companies controlled in excess of $80 \%$ of the market, i.e. Old Mutual and Sanlam. The operations of these two companies represent the dominant trends in the long-term insurance industry. 
TABLE 2: Number of Long-Term Insurance Companies, 1985-2000

\begin{tabular}{lcccc}
\hline & 1985 & 1990 & 1995 & 2000 \\
\hline Long Term: Primary & 51 & 32 & 39 & 64 \\
Long Term: Reinsurance & 6 & 6 & 6 & 6 \\
Long Term Total & 57 & 38 & 45 & 70 \\
\hline
\end{tabular}

Source: Registrar of Insurance, 1985-1997; Registrar of Long Term Insurance, 1998-2000

In 1999 two new acts took effect, The Long Term Insurance Act, No 52 of 1998 and The Short Term Insurance Act, No 53 of 1998, replacing the 1943 Insurance Act. In future all long-term business will be regulated by the Registrar of Long Term Insurance in the Financial Services Board, which was established in 1990. The Registrar of Short Term Insurance regulates only the short end of the market. No composite insurance companies were permitted to conduct business after 1999. Long-term insurance companies could, nevertheless, acquire shares in short-term companies, but operations had to be separated entirely. This was the result of the liquidation of a large short-term insurance company, AA Mutual Insurance Association in 1986 (Benfield \& Vivian, 2003).

As reflected in TABLE 3, the net annual premium income of long-term insurance companies increased dramatically $-82.33 \%$ between 1985 and 1990 , or at an average annual growth rate of $16.47 \%$, by $53.84 \%$ between 1990 and 1995 , or annual average of $10.6 \%$, and by $94.56 \%$ between 1995 and 2000 , or annual average of $18.9 \%$. This increase in premium income during the latter half of the 1980s could be ascribed to the high inflationary environment, but since the 1990 s the increase was well in excess of GDP and inflation growth.

TABLE 3: Income and expenditures of long-term insurance companies, 1985-2000 ( $R^{\prime} b n$ )

\begin{tabular}{lcccc} 
& 1985 & 1990 & 1995 & 2000 \\
\hline Income & 7.09 & 40.14 & 86.97 & 190.94 \\
\hline Net premiums & 4.15 & 21.18 & 61.77 & 144.47 \\
\hline Investment income & 2.12 & 10.58 & 23.17 & 34.94 \\
\hline Other income & 0.7 & 7.75 & 2.02 & 1.53 \\
\hline Expenditure & 2.43 & 16.63 & 53.70 & 140.68 \\
\hline Benefits & 1.51 & 12.22 & 44.61 & 118.23 \\
\hline Management Expenditure & 0.4 & 1.97 & 4.49 & 9.01 \\
\hline Commissions & 0.35 & 1.79 & 4.52 & 6.06 \\
\hline Other expenditures & 0.02 & 0.66 & 0.08 & 7.38 \\
\hline Ratio: Income-expenditure & 2.8 & 2.41 & 1.62 & 1.36 \\
\hline \% five years change in income & & $82.33 \%$ & $53.84 \%$ & $94.56 \%$ \\
\hline \% five year change in expenditure & & $85,38 \%$ & $69,03 \%$ & $61,82 \%$ \\
\hline
\end{tabular}

Source: Registrar of Insurance, 1985-1997; Registrar of Long Term Insurance, 1998-2000

The strong premium growth was undermined by the steady growth in benefits paid: between 1985 and 1990 benefits paid rose by $17.52 \%$ per annum, which exceeded the inflation rate. Between 
1990 and 1995 the annual increase of benefits paid rose by $14.5 \%$, and between 1995 and 2000 by $12.45 \%$ per annum. This trend shows that funds were flowing out of the industry more rapidly than the reverse inflow of funds. The outflow of funds from the long-term insurance industry is also reflected in the declining ratio of income to expenditure. In the period between 1985 and 1990 the ratio of income to expenditure was 2.8 but then steadily declined to 1.36 by 2000 . A similar trend can be expected in the ratio of assets to liabilities. In TABLE 4 the ratio of assets to liabilities declined from 1.78 in 1985 to 1.27 in 1995 and then strengthened slightly to 1.41 by 2000. (This ratio declined further to 1.10 in 2002.) The outflow of funds from the long-term insurance industry, as well as the weakening asset/liability ratio, meant that surplus assets came under increasing pressure. This trend restricted the ability of insurance companies to strengthen solvency bases and limited any strategic change in business operations.

TABLE 4: Long-term insurance companies' assets and liabilities, 1985-2000 (R'bn)

\begin{tabular}{lcccc}
\hline & 1985 & 1990 & 1995 & 2000 \\
\hline Assets & 28.83 & 141.54 & 369.75 & 709.38 \\
Liabilities & 16.17 & 104.68 & 305.36 & 601.36 \\
Assets/Liabilities & 1.78 & 1.35 & 1.27 & 1.41 \\
\hline
\end{tabular}

Source: Registrar of Insurance, 1985-1997; Registrar of Long Term Insurance, 1998-2000

The nature of long-term insurance companies' business operations is illustrated in TABL $\mathbf{5}$. The substantial exposure to pension funds and group life schemes was sustained. These are not risk products, but in effect a fund management function, since the long-term insurance companies either managed pension funds (or employee benefit schemes) independently or on behalf of smaller employers. These funds rose from R1.87 billion in 1985 to R66.92 billion in 2000, or from $45.06 \%$ of the business of the long-term insurance companies to $49.63 \%$ in 2000 . This development is attributed to the large number of 'new' employees in government service (the large increase of civil servants under the new government after 1994) and the rise of a new black middle class who entered permanent employment for the first time. In the absence of state social security, private pension funds as a mechanism of defined contribution savings options, mushroomed. By 2000 total assets of pension funds constituted $75.26 \%$ of GDP (Vivian, 2007).

TABLE 5: Product segmentation in the long-term insurance market, 1985-2000 (R'bn)

\begin{tabular}{lcccc}
\hline & 1985 & 1990 & 1995 & 2000 \\
\hline $\begin{array}{l}\text { Pension Fund + Group } \\
\text { Life Benefits }\end{array}$ & & & & \\
$-\quad$ Premiums & 1.87 & 7.72 & 20.98 & 66.92 \\
$-\quad \%$ & 45.06 & 35.21 & 34.20 & 49.63 \\
\hline $\begin{array}{l}\text { Retirement Annuity } \\
\text { Fund Business }\end{array}$ & & & & \\
$-\quad$ Premiums & 0.63 & 2.63 & 4.49 & 10.39 \\
\% & 15.16 & 12.01 & 7.32 & 7.70 \\
$\begin{array}{l}\text { Immediate Annuity } \\
\text { Business }\end{array}$ & & & &
\end{tabular}




\begin{tabular}{|c|c|c|c|c|c|}
\hline & & 1985 & 1990 & 1995 & 2000 \\
\hline - & Premiums & 0.21 & 3.83 & 10.04 & 12.01 \\
\hline - & $\%$ & 5.13 & 17.49 & 16.37 & 8.90 \\
\hline \multicolumn{6}{|c|}{$\begin{array}{l}\text { Disability and Health } \\
\text { Insurance }\end{array}$} \\
\hline - & Premiums & 0.02 & 0.19 & 1.4 & 2.79 \\
\hline- & $\%$ & 0.54 & 0.85 & 2.30 & 2.07 \\
\hline \multicolumn{6}{|c|}{ Single Premiums } \\
\hline- & Premiums & 0.07 & 0.27 & 5.42 & 17.85 \\
\hline - & $\%$ & 1.75 & 1.24 & 8.84 & 13.24 \\
\hline \multicolumn{6}{|c|}{ Periodic Premiums } \\
\hline- & Premiums & 1.34 & 7.28 & 18.99 & 24.90 \\
\hline - & $\%$ & 32.31 & 33.21 & 30.96 & 18.46 \\
\hline \multicolumn{6}{|c|}{ Total } \\
\hline- & Premiums & 4.15 & 21.92 & 61.32 & 134.84 \\
\hline - & $\%$ & 100 & 100 & 100 & 100 \\
\hline
\end{tabular}

Source: Registrar of Insurance, 1985-1997; Registrar of Long Term Insurance, 1998-2000

The relative decline in retirement annuity business from $15.16 \%$ in 1985 to $7.70 \%$ in 2000 indicates that investors moved increasingly to alternative investment instruments to provide for future needs. This trend is underlined by the similar trend displayed in periodic premium policies - these declined from $32.31 \%$ of long-term insurance business to $18.46 \%$ in 2000 . The trend was similar for immediate annuity investments.

The product segmentation distribution of long-term insurance companies between 1985 and 2000 illustrates another important trend. Old Mutual and Sanlam dominated the long-term insurance market, but the demutualisation of those companies in 1998 resulted in a strategic transformation of the business direction of both concerns. Both were transformed into listed diversified financial services companies. The growth in pension funds under administration and the rise in single premium policies to $62.87 \%$ of business show that the market placed sufficient confidence in the ability of the newly listed entities to manage investment funds effectively. When the $7.07 \%$ RA funds under administration, which is also a fund management function, is added, this proportion is $69.94 \%$, almost three-quarters of the business of long-term insurance companies. This trend refutes agency problems as a reason for demutualisation. The change in product distribution in long-term insurance companies' assets is rather an illustration of the industry's transformation in response to international financial market adjustments after liberalisation. Domestic markets were deregulated and interfaced increasingly with international markets, ending the insulation and isolation of the financial services industry in South Africa. 


\section{DEMUTUALISATION : SOUTH AFRICA}

The financial services landscape was completely reconfigured by the recommendations of the De Kock Commission and subsequent deregulation in South Africa in response to international deregulation (Singleton \& Verhoef, 2010). The changing landscape of the deregulated international financial environment and the political changes in South Africa by the early $1990 \mathrm{~s}$ also had an impact on the corporate strategy of long-term insurers. Exchange control from the 1970 s prevented long-term insurers from global investment, but by the early 1990 s significant relaxation of exchange controls changed the strategic options available to long-term insurers. In 1992 the Financial Institutions Amendment Act, No 83 of 1992 was passed, permitting investments in instruments of institutions incorporated outside South Africa (FSB Annual Report, 1991). These developments coincided with international trends to break up large diversified conglomerates, the so-called 'unbundling' exercise. Expansion into global investment markets offered increased flexibility to long-term insurers.

\subsection{Sanlam Case Study}

Sanlam wanted to establish itself internationally as a global financial services group, and by reducing its exposure to diversified conglomerates, formulated a new vision to use those proceeds to finance international transactions. The only remaining investments to be considered strategic to Sanlam were Santam, ABSA and Genbel (Sanlam Minutes of Board Meeting, 16/8/95). In 1990 the chief actuary of Sanlam suggested that the company explore avenues to optimise profits on investments, lower costs and distribute risks more equitably. To achieve this the 'mutual' should no longer be managed as a mutual that, by definition, had no 'capital', but it should approach its free assets as an 'estate' or 'capital' and manage that to optimise returns to profit-sharing policyholders in the long run (Confidential Memorandum Rudman - P Steyn, 16/01/90). By 1995 Sanlam's competitive position in the long-term insurance industry was dire, as illustrated in TABLE 6.

TABLE 6: Sanlam accumulated surplus and policy liabilities, 1986-1994

\begin{tabular}{lccccc}
\hline & $\begin{array}{c}\text { Accumulated } \\
\text { surplus (1) } \\
R^{\prime} m\end{array}$ & $\begin{array}{c}\text { Total policy } \\
\text { liabilities (2) } \\
R^{\prime} m\end{array}$ & $\begin{array}{c}\text { Policyliabilities (market } \\
\text { related/linked policies } \\
\text { excluded) } \\
R^{\prime} m\end{array}$ & $\begin{array}{c}1 \div 2 \\
\%\end{array}$ & $\begin{array}{c}1 \div 3 \\
\%\end{array}$ \\
\hline $30 / 09 / 86$ & 1402 & 10942 & 4078 & 12.8 & 34.4 \\
$30 / 09 / 87$ & 1455 & 17046 & 6044 & 8.5 & 24.1 \\
$30 / 09 / 88$ & 1493 & 19231 & 8007 & 7.8 & 18.6 \\
$30 / 09 / 89$ & 1686 & 29950 & 12097 & 5.6 & 13.9 \\
$30 / 09 / 90$ & 1697 & 34449 & 15117 & 4.9 & 11.2 \\
\hline $30 / 09 / 91$ & 1745 & 47279 & 20961 & 3.7 & 8.3 \\
$30 / 09 / 92$ & 1805 & 56455 & 25881 & 3.2 & 7.0 \\
\hline $30 / 09 / 92$ & 2100 & 67669 & 32076 & 3.1 & 6.5 \\
$30 / 09 / 94$ & 3200 & 86463 & 41531 & 3.7 & 7.7 \\
\hline
\end{tabular}

Source: Sanlam Archives: Sanlam Minutes of Board Meeting, 19/04/95 
A decline from $12.8 \%$ in 1986 in accumulated surplus to liabilities to $3.7 \%$ in 1994 , or from $34.4 \%$ of accumulated surplus to liabilities (excluding market related policies) to $7.7 \%$ in 1994 , indicated that Sanlam had less impressive assets in its capital portfolio and that payments under market-related or linked products were too high. Policyholders were increasingly migrating from such products. Finally Sanlam placed too heavy an emphasis on growth in premium income and market share and insufficient emphasis on profitability. Between 1987 and 1994 Sanlam's operating profit on average was $6 \%$, which represented a fluctuation between losses in 1988, 1990 and 1992 (6\%) and a high of 20\% in 1993 (Sanlam Minutes of Board Meeting, 19/04/95).

TABLE 7: The long-term insurance industry, 1994

\begin{tabular}{lcccccc}
\hline & $\begin{array}{c}\text { Sanlam } \\
R^{\prime} m\end{array}$ & $\begin{array}{c}\text { Old } \\
\text { Mutual } \\
R^{\prime} m\end{array}$ & $\begin{array}{c}\text { Liberty } \\
\text { Life } \\
R^{\prime} m\end{array}$ & $\begin{array}{c}\text { Southern } \\
R^{\prime} m\end{array}$ & $\begin{array}{c}\text { Momen- } \\
\text { tum } \\
R^{\prime} m\end{array}$ & $\begin{array}{c}\text { Metropo- } \\
\text { litan } \\
R^{\prime} m\end{array}$ \\
\hline $\begin{array}{l}\text { Policy liabilities (1) } \\
\begin{array}{l}\text { Total accumulated } \\
\text { surplus (2) }\end{array}\end{array}$ & 86463 & 89648 & 71121 & 19937 & 8118 & 4126 \\
\hline $2 \div 1$ & 3200 & 17471 & 21976 & 2692 & 890 & 2238 \\
\hline $\begin{array}{l}\text { Total premium } \\
\text { income }\end{array}$ & 14211 & 14976 & 5233 & 3565 & 1299 & 1221 \\
\hline \begin{tabular}{l} 
Market share \% \\
\hline
\end{tabular} & 30.2 & 31.8 & 11.1 & 7.6 & 2.8 & $2.6 \%$ \\
\hline
\end{tabular}

Source: Sanlam Archives: Sanlam Minutes of Board Meeting 19/04/95

Although Sanlam had complied with the capital adequacy ratio set by the Society of Actuaries of South Africa and the Registrar of Insurance Companies (between $3 \%$ and $4 \%$ ), Sanlam maintained a ratio between $2 \%$ and $3 \%$ from 1986. There was no room for a further deterioration in the capital position of Sanlam. Sanlam had the lowest ratio of accumulated surplus to liabilities in the market despite a $30.2 \%$ market share of total premium income (see TABLE 7 ). A serious problem existed in the management of assets. Despite several generic 'industry problems', such as increasing AIDS-related claims, disclosure and transparency in accounting practices in the industry, the revolution in information and communication technology, changes in the investment environment, strong competition from non-traditional role players, increased regulation by the authorities, internationalisation of the industry and the investment environment, an apparent negative disposition of government to big business groups, changes in the socio-political industry environment, and the potential creation of a national pension fund, medical and provident scheme, Sanlam had a few positive factors in its favour. Sanlam could benefit from its substantial market share, low unit costs, respect in its traditional target markets, recognition of its leadership in the economy and excellent national infrastructure. The problems that confronted Sanlam included a lack of vision in management, unfavourable positioning for the new socio-political environment where the traditional Afrikaner orientation was not perceived favourably in the early 1990s, low capital, a higher percentage fixed cost, non-competitive information technology competency, lagging behind its competitors in terms of mobile computing, adjusting too slowly in a rapidly changing financial environment (it suffered from the so-called 'big ship' syndrome), and the size of its investment portfolio limited efficient adaptation. Also Sanlam's unit trust returns were lagging behind the industry and so did its growth in premium income. Management was not business-oriented and suffered from a 
bureaucratic approach, insufficient client orientation, limited profit orientation and was more operational than strategically oriented. The following serious threats were identified: greater disclosure of its capital position, commission buyback values, future changes to commission bases and buyback values. The AIDS risk-related problems in the non-traditional markets seemed serious. The cost of compulsory affirmative action policies also constituted a risk. The company also feared the reintroduction of compulsory investments and it was cautious about the potential impact of future capital gains tax (Sanlam Confidential Memorandum, 19/04/95).

Demutualisation could offer access to capital, a more flexible management structure which is more conducive to operations within a group structure, greater flexibility in mergers and acquisitions, incentive remuneration to managers and an overall profit orientation as a result of a stronger focus on capital management. Potential disadvantages were the inequitable profit distribution between shareholders and policyholders, potential bias in favour of shareholders because it would be in management's interest to favour shareholders, a potential credibility crisis among policyholders when mutuality was exchanged for a proprietary company. A more serious question was: who would control a new demutualised entity? Given the political changes in the country, policyholders might be concerned about the possibility of the acquisition of a controlling interest by the 'new role players' or the state (Sanlam Minutes of Board Meeting, 15/02/95; Sanlam Board of Directors, Confidential Memorandum: 15/04/95; APZ e@mail, 25/11/09).

Sanlam experienced no capital risk, but also had '... no publicly traded ownership rights.' Two avenues were open to access additional capital - either demutualise or issue 'surplus notes' (Carson et al, 1998; Meador \& Chugh, 2006). The fact that long-term insurers were not permitted to invest abroad, because the capital was required to cover policy responsibilities or comply with capital adequacy requirements, placed a major limitation on ambitions to enter international financial services markets. Sanlam's capital base constituted a serious limitation to global expansion.

Management in Sanlam was torn between two choices: honour its historic legacy as a trusted mutual and serve the interests of policyholders seeking security and stability, or venture into the dynamic market opportunities opened by global financial deregulation. The clear shift in investor preferences away from traditional life insurance towards wealth management/annuity markets created new opportunities, as identified by Meador and Chugh (2006), was also an opportunity for Sanlam. The Sanlam management acknowledged the global decline in the traditional life insurance markets following adverse changes in the life insurance tax environment, uncompetitive cost structures in the industry, competition by direct insurers and costly time consuming marketing (Sanlam Minutes of Management, 25/09/95; Vivian, 2007). In the long-term insurance industry withdrawals in relation to inflows expressed as a ratio of income to expenditure declined, as illustrated in Table 3 - income as a ratio of expenditure declined from 2.8 in 1985 to 1.36 in 2000. In 2001 premium inflows displayed a negative inflow of $2 \%$. The number of surrendered policies as a proportion of new policies rose from $16.9 \%$ in 1995 to $25 \%$ in 1999 , while the number of policy lapses as a proportion of new business rose from $25.9 \%$ in 1995 to $30.9 \%$ in 1999 (FSB, 1999). Sanlam recognised the changing nature of the longterm insurance industry as well as growing investor dissatisfaction with the transparency of long-term insurers' financial statements. These industry trends signalled the need for a fundamental overhaul of its core business.

Despite serious attempts to change the strategic focus of Sanlam after 1995, it was apparent that a fundamental organisational shift was required. Financial analysts were ad idem that 
Sanlam was in trouble and needed a turn-around strategy (Finweek, 11/03/10). In May 1997 the Board of Sanlam was advised: 'The new competitive environment is forcing many mutual insurers to focus exclusively on its [sic] core business (a niche strategy) or, alternatively, seeking [sic] to gain a competitive edge by positioning itself [sic] as a national or global player [sic] offering the full range of financial products ... We feel that the mutual structure will best support an institution following the niche strategy. However, the need to reposition itself as a multi-line financial service provider with international presence will require substantial restructuring, often involving demutualisation' (Sanlam Board, Confidential Memorandum, 17/04/97). The board agreed on a strategy to migrate from a life assurance company to a financial services institution, from a local South African company to an international company, and from an undercapitalised company to a well-capitalised company (Sanlam Minutes of Board Meeting, 27/05/97). The board of Sanlam decided in October 1997 to demutualise and a public announcement to that effect was made on 29 January 1998. The demutualisation proposal was put to an extraordinary general meeting of the Sanlam shareholders on 15 October 1998 and ratified. Sanlam Limited listed on the Johannesburg Securities Exchange on 30 November 1998. The demutualisation raised R4 billion and it was envisaged that that access to substantially increased capital resources would enable Sanlam to become a world-class financial services group (Business in Africa, 16/04/98).

\subsection{Demutualisation of Old Mutual}

The deregulated financial market environment was a very strong incentive for Old Mutual to expand its business operations. After 1990 Old Mutual expanded its long-term insurance operations into Africa, establishing branches in Malawi, Namibia, and Zimbabwe as well as in Bermuda, Guernsey, and Hong Kong. Old Mutual was the largest long-term insurance company in South Africa, with a market capitalisation of R40 billion. The management of Old Mutual justified demutualisation as vital to take advantage of the globalisation of financial markets (The Economist, 22/02/98). From a position of relative strength, Old Mutual announced its intention to demutualise. The first reason given was the globalisation of the financial services industry. The company also acknowledged the change in demand - traditional demarcation lines disappeared and clients developed preferences for a wide range of financial services from a single supplier. Restrictive regulatory requirements on mutual insurers served to limit optimisation of capital at hand. From the perspective of existing policyholders, Old Mutual argued that the capital adequacy requirements of a mutual life insurer were 'very substantial'. Old Mutual was required to hold approximately R31 billion, just as security for policyholders. The benefit to policyholders depended on the freedom of investment to optimise return of policyholder funds. If the company demutualised, the capital of the company would be retained, but the '.... value unlocked so that they can enjoy realisable assets that fully reflects the value of the capital and of business on books, furthermore enhanced by the extra value that the market may place on the business as an on-going concern' (Old Mutual, 1999). The strategic desire for increased operational freedom was expressed by reference to the restrictions placed on the mutual company to dispose of shareholding in certain acquired 'proprietary subsidiaries'. Old Mutual was referring to its controlling interest in the short-term insurance company Mutual \& Federal and in the fourth-largest banking group, Nedcor Limited, which has '... become much greater in weighting than would be considered appropriate on normal investment criteria' (Old Mutual, 1999). Greater freedom to structure the investment portfolio was preferred. This could be achieved through holding operating subsidiaries in the holding company. That would allow the structuring of investment portfolios backing policyholder commitments outside the 
constraints of the group structure. Portfolio managers would be free to invest in quoted subsidiaries to the extent appropriate to their investment strategies.

Old Mutual was not in a similar weak financial position as Sanlam was when it considered demutualisation, but it was envisaged that future capital requirements might exceed the capacity of a mutual life insurer. Old Mutual had conducted a conscious capital management programme since 1993 in each of the territories in which it operated. This strategy entailed recognising the major part of free assets as corporate capital to ensure security and investment flexibility. A portion of the profits was retained for the capital account from all business activities and internal guidelines were developed for profit and risk allocation between the capital account and high-risk policyholders. These measures left Old Mutual with a strong capital position in 1999 but the management envisaged future expansion, which could require access to external capital too extensive to be raised in the domestic market by a mutual society. Management stated: 'If demutualisation is done from a position of strength, as Old Mutual is doing, it can be structured so as to optimise the benefits to current members, both as on-going policyholders and as the initial shareholders in the new enterprise' (Old Mutual, 1999).

It was apparent that Old Mutual harboured international expansion visions. The Old Mutual demutualisation strategy differed fundamentally from Sanlam's. Demutualisation was structured in such a way that Old Mutual listed as a primary listing on the London Stock Exchange and on the JSE only as a secondary listing. The primary listing was the new holding company: Old Mutual plc, incorporated under United Kingdom law, on the London Stock Exchange. Business operations in the various geographical locations were structured as separate subsidiaries - Old Mutual Life Assurance Company (South Africa) Limited, Old Mutual Life Assurance Company (Bermuda) Limited, Old Mutual Life Assurance Company (Namibia) Limited, Old Mutual Life Assurance Company (Zimbabwe) Limited and Old Mutual Life Assurance Company (Malawi) Limited. The interests in Guernsey and Hong Kong were structured under the South African subsidiary (Old Mutual, 1999b; 1999c). The primary benefits conveyed to policyholders due to demutualisation were better capitalisation of the company and a ready access to external capital markets (Old Mutual 1999). No reference was made in the published documents to the socio-political conditions in South Africa. The restructuring of the Old Mutual group of companies indicated that the spreading of operations in various global markets was seen to be a wise strategy to enhance access to additional capital as well as to protect existing policyholders' and future shareholders' interests. When Old Mutual demutualised in September 1999, its market capitalisation increased to R40 billion on the JSE, positioning the company for the global expansion it aspired to (Finweek,18/12/2008).

\section{CONCLUSION}

Global deregulation of financial markets had a direct impact on the regulatory environment in South Africa. In the context of neo-liberal market-oriented economic policies, the dominant long-term insurance companies realised that they needed to reinvent themselves as globally competitive financial services companies. An isomorphic transformation was imminent since the financial environment in which they operated had changed so fundamentally. The former mutual organisational form increasingly imposed restrictions on operational flexibility in the changed global financial environment. Entering competitive markets as a public listed company would create the most appropriate vehicle to compete in those markets. The 'shareholder-value ideology' gained ground in the opening up of international markets and brought about a cultural 
change in management, as observed by Marshall et al. (2003). With pressures from both directions - client demands and global financial market competition - demutualisation opened the avenue to offering a wide variety of financial services, from life and general insurance to banking and investment services. The fundamental transformation of client demand for wealth products was illustrated by the changing composition of the long-term insurers' liabilities. Both Sanlam and Old Mutual had the legacy of very large subsidiary investments, which limited investment flexibility and optimal investment returns on policyholders' funds. The decline in the demand for traditional life insurance products did not constitute a lack of confidence in the managerial capacity of the long-term insurers since funds were still flowing into the companies. The choice of investment instruments was severely compromised by the regulatory environment of mutual long-term insurers. Management sought the freedom of the market. It was assumed that operational flexibility would simultaneously be in the interest of the policyholder and the shareholder.

Demutualisation had two important consequences for the two South African life insurance companies and the long-term insurance industry in South Africa. The 'regulatory space' had changed fundamentally. Global responsiveness was required. First, the financial reporting requirements of the JSE for newly listed entities highlighted a disclosure deficiency in South African Generally Accepted Accounting Practices (SA GAAP), which suited the long-term insurers, but indirectly affected them adversely. Exemption from consolidation of subsidiaries/associated companies in the financial statements of the holding company reduced the ability of investors/analysts to gain a full picture of the state of the entire group of companies. Limited disclosure could have an adverse effect on investment decisions. If mutual insurers demutualised inter alia to attract new capital from new global markets and expand operations beyond the traditional long term insurance business, enhanced disclosure and transparency was imperative. Secondly, the differences in SA GAAP, UK GAAP and USA GAAP highlighted difficulties in comparing the condition of companies operating in the same industry in different parts of the globe. As demutualisation in the Sanlam case had an explicit aim of attracting international investors' attention, comparability was compromised by differences in accounting principles. Globalisation of financial services was dependent on access to markets and movement of capital. Harmonisation of accounting principles could facilitate such investment flows.

Demutualisation placed these accounting concerns on the agenda. Sanlam emerged as a broadly based financial services group of companies '... able to provide clients with a comprehensive range of financial products' (Sanlam Share Offer Prospectus, 1998a:1). The listed entity was Sanlam Limited, which consisted of wholly owned subsidiary Sanlam Life Insurance Limited. The latter managed the Policyholders' Fund and the Shareholders' Fund. Sanlam Limited held direct investments in various other companies. Old Mutual emerged as a UK-listed public liability company, with subsidiaries in various African and international markets. After demutualisation Old Mutual embarked on dedicated global expansion strategies to acquire a global footprint. This strategy was not very successful and by 2008 the Sanlam market capitalisation exceeded that of Old Mutual (Finweek, 18/12/2008). The change in organisational form cannot be blamed for the weak strategic choices made by Old Mutual. Sanlam opted for slow growth from a strengthened domestic basis and this strategic choice finally paid off. 


\section{Acknowledgement}

The author wishes to extend her sincere gratitude to the following participants to the Dai-Ichi Life Research project on Insurance History, namely Takauyoneyama, Robin Pearson and Monica Kenneley for their invaluable comments on an earlier draft of this paper, as well as anonymous reviewers of the Journal of Financial and Economic Sciences for their comments to strengthen the quality of this contribution. Financial support for this research from the National Research Foundation is acknowledged. The responsibility for the views expressed in this contribution remains that of the author.

\section{LIST OF REFERENCES}

Amelina, M. (2002). What turns a kolkhoz into a firm? Regional politics and the elasticity of budget constraints. In O'Brien, D. J. \& Wegren, S.K. (eds). Rural reform in Post-Soviet Russia. Baltimore: John Hopkins University Press. (pp. 264-281)

Battilani, P. \& Schröter, H.G. (2011). 'Demutualization and its problems.' Quaderni Working Paper DSE No 762, Universita di Bologna.

Benfield, B.C. \& Vivian, R.W.(2003). Insurance in the 1990s. The South African Journal of Economic History, 18 (2), pp. 275-288.

Benfield, B.C. (1997). South African Life Assurance legislation; A Survey. South African Journal of Economics, 65 (4), pp. 568-594.

Birchall, J. (1998). The Future of Cooperative and Mutual Business, Research and Report, Meiji University.

Business in Africa, 16-30/04/1998, p.3.

Cagle, J.A.B. , Lippert, R.L. \& Moore, W.T. (1996). Demutualization in the Property-Liability Insurance Industry. Journal of Insurance Regulation, 14 (3), pp. 343-369.

Callon, M. (1986). Some elements of a sociology of translation: Domestication of the scallops and the fishermen of Saint Brieuc Bay. In Law, J. (ed). Power, action and belief: A new sociology of knowledge? London: Routledge \& Kegan Paul. (pp.196-233).

Carrasco, I. (2004). The Global financial environment and Spanish cooperative banking, IAER, 10(4), pp. $265-272$.

Carson, J.M., Forster, M.D. \& McNamara, M.J. (1998). Change in Ownership Structure: Theory and Evidence from Life Insurance Demutualizations. Journal of Insurance /ssues, 21 (1), pp. 1-22.

Chaddad, F. \& Cook, M. (2004). The Economics of Organization Structure: A U.S. Perspective on Demutualization. Annuals of Public and Cooperative Economics, 75 (4), pp. 575-594.

Collins, R.A. (1991). The Conversion of Cooperatives to Publicly held Corporations: A Financial Analysis of Limited Evidence. Western Journal of Agricultural Economics, 16(2), pp. 326-330.

Cook, M. (1995). The future of U.S. agricultural cooperatives: a neo-institutional approach. American Journal of Agricultural Economics, 77, pp. 1153-1159.

Cook, J.S. Deakin \& Highes, H. (2001). Mutuality and Corporate Governance: The Evolution of UK Building Societies Following Deregulation. Working Paper 205, June 2001 ESCR Centre for Business Research, University of Cambridge. 
Cummins, D.J. , Weiss, J.M. \& Zi, H. (1999). Organizational Form and Efficiency: The Coexistence of Stock and Mutual Property-Liability Insurers. Management Science 45(9), pp. 1254-1269.

Erhemjamts, 0. \& Leverty, J.T. (2007). The demise of the mutual organizational form: An investigation of the life insurance industry. Waltman, M.A.: Bentley College.

Ernest \& Young (2004) Mergers and Acquisitions. Review of activities in the year 2004.

Fama, E.F. \& Jensen, M.C. (1983). Agency Problems and Residual Claims. Journal of Law and Economics. 26 (4), pp. 327-349.

Financial Services Board. (1991). Annual Report of the Registrar of Long Term Insurance. Pretoria.

Financial Services Board. (1999). Annual Report of the Registrar of Long Term Insurance. Pretoria.

Financial Services Board. (2009). Annual Report of the Registrar of Long Term Insurance. Pretoria.

Finweek, 18/12/2008, p.20.

Finweek, 11/03/2010, p. 16-19.

Fulton, M. (1995). The Future of Co-operatives in Canada. A Property Rights Approach. American Journal of Agricultural Economics, 77, pp.1144-1152.

Goedhuys, D. (1994). South African monetary policy in the 1980s: Tears of reform and foreign financial aggression. South African Journal of Economic History, 9(2), pp.145-164.

Hansmann, H. (1985). The organisation of insurance companies: mutual versus stock. Journal of Law, Economics and Organisation, 1(2), pp. 125- 153.

Hansmann, H. (1996). The Ownership of Enterprise. Harvard University Press: Massachussetts.

Hetherington, J.A. (1969). Fact v. Fiction: Who Owns Mutual Insurance Companies. Wisconsin Law Review. November, pp. 1068-1103.

Hodge, D. (2001). A Tale of two governors. Monetary policy and the South African economy, 19811999. The South African Journal of Economic History, 16(1), pp. 47-73.

Hölstrom, B. (1999). The Future of Cooperatives: A Corporate perspective. TLA,4.

Jensen, M.C. \& Meckling, W.H. (1976). Theory of the Firm: Managerial Behavior, Agency Costs and Ownership Structure. Journal of Financial Economics, 3 (4), pp. 305-360.

Jones, S. \& Muller, A.L. (1992). The South African Economy, 1910 -1990. Macmillan: London.

Jones, F.S. (ed). (2002). The Decline of the South African Economy. Edward Elgar: Cheltenham.

Leyshon, A. \& Pollard, J. (2000). Geographies of Industrial Convergence: The Case of Retail Banking. Transactions of the Institute of British Geographers, New Series, 25 (2), pp. 203-220.

Llewellyn, D.T. (1992). Building Societies. In Newman, P., Murray, M. \& Eatwell, J. (eds) The New Palgrave Dictionary of Money and Finance. London: Macmillan. (pp. 249-251)

Llewellyn, D.T. (1996). Banking in the 21st Century: The Transformation of an Industry. RBA 1996 Conference: Future of the Financial System, July, pp. 80-90.

Llewellyn, D.T. (1997). Reflections on Mutuality v. Conversion Debate. Loughborough University Banking Centre-Building Society Association Project. Paper No 1. Building Society Association: London. 
Maasdorp, G. (2002). Economic Survey, 1970-2000. In Jones, F.S. (ed) The Decline of the South African Economy. Edward Elgar: Cheltenham. (pp. 7-30).

Marshall, J.N. \& Willis Richardson, R. (2003). Demutualisation, Strategic Choice and Social Responsibility. Environment and Planning C: Government and Policy, 21, pp. 735-760.

Martin, R. \& Turner, D. (2000). Demutualization and the Remapping of Financial Landscapes. Transactions of the Institute of Geographers, New Series, 25 (2), pp. 221-241.

Masulis, R.W. (1987). Changes in Ownership Structure: Conversions of Mutual Savings and Loan to Stock Charter. Journal of Financial Economics, 1(1), pp. 29-59.

Mayers, D. \& Smith, C.W. (1981). Contractual Provisions, Organizational Structure and Conflict Control in Insurance Markets. The Journal of Business, 54 (3), pp. 407-434.

Mayers, D. \& Smith, C.W. (1986). Ownership structure and control: The mutualisation of stock life insurance companies. Journal of Financial Economics, 16 (1), pp. 73-98.

Mayers, D. \& Smith, C.W. (1994). Managerial Discretion, Regulation and Stock Insurance Ownership Structure. The Journal of Risk and Insurance, 61 (4), pp. 638-655.

Mayers, D. \& Smith, C.W. (2002). Ownership Structure and Control: Property-Casualty Insurer Conversion to Stock Charter. Journal of Financial Services Research, 21(1/2), pp. 117-144.

McKnight, E. \& Gething, H. (1996). Demutualisation. A Special commissioned report. FT Law \& Tax. Pearson: London.

McNamara, M.J. \& Rhee, S.G. (1992). Ownership Structure and Performance: The Demutualization of Life Insurers. Journal of Risk and Insurance, 59 (2), pp. 221-238.

Meador, J.W. \& Chugh, L. (2006). Demutualization in the Life Insurance Industry: A Study of Effectiveness. Review of Business, 27 (1), pp. 10-17.

Michie, J., Llewellyn, D.T., Anderson, D., Eyre, N. \& Hunt, N. (2009). Converting Failed Financial Institutions into Mutual Organisations. A Report from the Oxford Centre for Mutual \& Employeeowned Business. Kellogg College, University of Oxford, Building Societies Association.

Mouritsen, J. \& Kreiner, K. (2003). Not for profit- For sale: Management control in and of an internet start-up company. In A Bhimani (ed) Management accounting in the digital economy. Oxford University Press: Oxford. (pp. 169-184.)

Nicols, A. (1967). Stock versus Mutual Savings and Loan Associations: Some Evidence of Differences in behaviour. The American Economic Revie, 57(2), pp. 337-346.

Old Mutual. (1999). The Demutualisation Proposal: Supplementary Documents. Financial Information. Cape Town.

Old Mutual. (1999b). The Demutualisation Proposal: Supplementary Documents. Scheme Documents. Cape Town.

Old Mutual. (1999c). The Demutualisation Proposal: Supplementary Documents. Memorandumand Articles of Associatin. Cape Town.

Perks, R.W. (1991). The Fight to stay Mutual: ABBEy Members against flotation versus ABBEy National Building Society, Annals of Public and Co-operative Economics, 62, pp. 393-430.

Rajan, R.G. \& Zingales, L. (2003). The great reversals: The politics of financial development in the twentieth century, Journal of Financial Economics, 69(1), pp. 5-50. 
Registrar of Insurance Companies, (1985- 1997). Annual Report. Government Printer: Pretoria.

RP70/1984. (1984). Final Report of the Commission of Inquiry into the Monetary System and Monetary Policy in South Africa. (De Kock Commission). Government Printer: Pretoria.

Sanlam. (1998a). Sanlam Share offers. Prospectus. Sanlamhof, Belville.

Sanlam. (1998b). Demutualisation Proposal. Information Memorandum. Sanlamhof, Belville.

Sanlam Archives: Minutes of Board Meetings, 1994-1999.

Sanlam Archives: SA5/3/12/6/8: WJ Harris Memorandum: Consolidation of Santam and Equity Accounting of Gensec and ABSA. 7/1/98

Sanlam Archives - Sanlam Board, Confidential Memorandum, 20/06/90; 15/05/91; 19/04/95.

- $\quad$ Confidential Memorandum Rudman- PSteyn, 16/01/90)

- $\quad$ Confidential Memorandum, 17/04/97)

- Sanlam Minutes of Board Meeting, 15/02/95: Confidential Memorandum: Rudman, 15/04/95.

- $\quad$ APZ e@mail, 25/11/09).

- $\quad$ Sanlam Minutes of Management Meeting, 25/09/95

- $\quad$ Sanlam Minutes of Board Meeting, 16/08/95; 15/02/95; 19/04/95; 27/05/97 ; 12/06/98: 10/06/98; 17/02/98; 20/01/98; 20/01/98; 7/02/98; 7/02/98.

- $\quad$ Sanlam Share Offer Prospectus (1998). Belville.

Schrader, L.F. (1989). Equity Capital and restructuring of cooperatives as investor=oriented firms. Journal of Agcricultural Cooperatives, 4, pp. 41-53.

Singleton, J. \& Verhoef, G. (2010). Regulation, Deregulation and Internationalisation in South African and New Zealand banking. Business History. 52 (4), pp. 536-563.

Skaerbaek, P. \& Tryggestad, K. (2010). The role of accounting devices in performing corporate strategy. Accounting, Organizations and Society, 35, pp. 108-124.

Skinner, I. \& Osborn, E. (1992). Changes in Banking in South Africa in the 1980s. In Jones, F.S. (ed). Financial Enterprise in South Africa since 1950. Macmillan: London. (pp. 62-79).

South African Reserve Bank, Time Series Data: www.resbank.co.za.

Stephens, M. (2001). Building society demutualisation in the UK, Housing Studies, 16, pp. 335-352.

Styger, P. \& Saayman, A. (2011). The Economic Architecture of the Two De Kocks. Economic History of Developing Regions, 26(Supplementary 1), pp. S21-S52.

Talbot, L. (2010). Of insane forms: from collectives to management controlled organisations to shareholder value organisation: building societies a case study, Journal of Financial Regulation, 11(3), pp. 223-239.

The Economist, 22/02/98.

Treptow, F. (2006). The Economics of Demutualization. An empirical analysis of the securities exchange industry. Deutscher Universitäts-Verlag: Wiesbaden.

Trinchet, J. (2003). The Evolution of the Financial System and the Efficiency of Intermediaries and Markets. In De Rosa, L. (ed). International Banking and Financial Systems. Evolution and Stability. Ashgate: Hants. (pp. 247-256). 
Tyler, G. (2003). UK building society demutualisation motives. Business Ethics: A European Review. 12 (4), pp.394-402.

Verhoef, G. (1987). The Establishment of the Netherlands Banking Tradition in a British Colony: the activities of the Netherlands Bank of Rhodesia/Rhobank, 1952 - 1980. The South African Journal of Economic History, 2(2), pp. 43-57.

Verhoef, G. (2003). The Invisible Hand: the roots of Black Economic Empowerment, Sankorp and societal change in South Africa, 1985 - 2000. Joernaal vir Eietydse Geskiedenis, 28(1), pp. 28-47.

Verhoef, G. (2009). Concentration and Competition: the changing landscape of the banking sector in South Africa, 1970- 2007. The South African Journal of Economic History, 24 (2), pp. 157-197.

Verhoef, G. (2010). 'Life Offices to the rescue.' A History of the Role of Life Insurance in the South African economy during the twentieth century. In Pearson, R. (ed). The Development of International Insurance. Pickering \& Chatto: London. (pp. 145-166)

Viswanathan, K.S. \& Cummins, J.D. (2003). Ownership structure change in the Insurance Industry: An Analysis of Demutualization. Journal of Risk and Insurance, 70(3), pp.401-437.

Vivian, R.W. (2007). South African Insurance markets. In Cummins, J. D. \& Venard, B. Handbook of International Insurance. Springer: New York. (pp. 677-738).

Von Wielligh, S. P. (2005). Financial reporting by South African long term insurers: A comparative study. Meditari Accountancy Research, l (1), pp. 67-86.

Wegren, S. K. (2009). Land reform in Russia. Institutional Design and Behaviour response. Yale University Press: New Haven.

* No access to Old Mutual private documents could be secured. The information in the public domain was the only to which access could be acquired. 